\title{
MALE REPRODUCTIVE ORGANS OF THE AFRICAN ELEPHANT, LOXODONTA AFRICANA
}

\author{
R. V. SHORT, T. MANN AND MARY F. HAY \\ Department of Veterinary Clinical Studies, and \\ A.R.C. Unit of Reproductive Physiology and Biochemistry, University of Cambridge
}

(Received 12th October 1966)

Summary. Results are presented of detailed dissections of the reproductive tracts of eight adult male African elephants and of one full-term male foetus, together with additional information obtained from the examination of a number of other bulls and cows.

A notable feature of the elephant's tract is the absence of a pampiniform plexus, cremaster muscle and inguinal canal; this is consistent with the intra-abdominal location of the testes. The weight of the testes and the mean diameter of the seminiferous tubules appear to be related to the size and hence the age of the animal. Active spermatogenesis was observed in all the adult testes examined. Testosterone was isolated from the testes and identified by infra-red spectroscopy; the testicular testosterone concentrations ranged from 3 to $490 \mu \mathrm{g} / 100 \mathrm{~g}$ testis and were apparently unrelated to season, age, behavioural status or vesicular fructose concentrations.

The elephant has no anatomically distinct epididymis. The wolffian duct is highly convoluted and probably several hundred metres in length. Its caudal half has an unusual histological appearance, with a very folded and extremely vascular lamina propria. The ampullae are large glandular structures, opening into the ducts of the corresponding seminal vesicles. The seminal vesicles are large, thick-walled sacs that contain up to $350 \mathrm{ml}$ of a watery secretion rich in fructose. The prostate varies in shape considerably between animals, being uni- or multilobular. The bulbo-urethral glands are large, and full of a highly viscous secretion.

The penis has a well-developed corpus cavernosum penis and large paired levator penis muscles on its dorsal surface.

The temporal gland is apocrine in nature, with a strongly smelling serous secretion. Its secretory activity appears to be unrelated to the reproductive status of the animal or the body temperature. The mean deep body temperature was found to be $36 \cdot 8^{\circ} \mathrm{C}$ (range $36 \cdot 2$ to $37 \cdot 5^{\circ} \mathrm{C}$ ).

Spermatozoa, recovered within 2 to 6 hours of death from the caudal end of the wolffian duct and the ampullae, were immotile, but could be partially activated by dilution with vesicular secretion. At least two of the elephants had had a retrograde ejaculation when they were shot, 
and in one instance motile spermatozoa were recovered from the bladder $6 \mathrm{hr}$ after death.

\section{INTRODUCTION}

The reproductive organs of the male elephant have been described by many distinguished investigators, Aristotle (Smith \& Ross, 1910) being amongst the first to recognize the intra-abdominal position of the testes. Some of the earlier anatomical studies are listed in the extensive bibliography on the elephant compiled by Shimizu, Fujita, Kamiya \& Isokawa (1960).

Within the last century, anatomical descriptions of the male reproductive tract of foetal, juvenile and adult Indian and African elephants have been published by Watson (1872), Mojsisovics (1879), Plateau \& Liénard (1881), Oudemans (1892), Weber (1898, 1927), Petit (1924), Eales (1929), Schulte (1937), Perry (1953) and Johnson (1963). Detailed accounts of the mating behaviour of domesticated Indian elephants are given by Slade (1903), of captive African elephants by Kühme (1963a, b), and of wild African elephants by Buss \& Smith (1966) and Short (1966).

The purpose of the present study has been to provide a detailed account of the endocrine activity of the testes, and the chemical nature of the secretions of the male accessory organs, of adult African elephants. We have also studied certain anatomical and histological features of the male reproductive tract, and have investigated the deep body temperature, and the secretory activity of the temporal glands.

\section{MATERIAL AND METHODS}

\section{MATERIAL}

Five sexually mature bulls and five cows (one with a full-term male foetus) were shot in the Trans-Mara district of Kenya in June 1962. All these animals except bull No. 5 were killed by heart shots. Three sexually mature bulls and two cows were killed by brain shots in the Queen Elizabeth National Park, Uganda, from January to March 1965. Formalin-fixed and frozen testicular tissue was obtained from sexually mature bulls shot in the Masindi and Butiaba districts of Uganda during the period July to September 1963, and formalin-fixed temporal glands from two male and eighteen female elephants shot on the Galana River Game Management Scheme, Kenya. Formalin-fixed testes and temporal glands were available from four bulls shot in the Kruger National Park, South Africa.

At the beginning of this study, there were no reliable methods available for determining the age of elephants. Two such methods, which are not completely in agreement with one another, have recently been published (Johnson \& Buss, 1965; Laws, 1966). It seems clear that, contrary to an earlier report (Perry, 1954), the tusks of both male and female African elephants continue to grow throughout life (Laws, 1966). Tusk weight, total body weight, shoulder height and degree of molar tooth wear can all be used to give an indication of the age of an animal, and some of these details are listed in Table 1. 


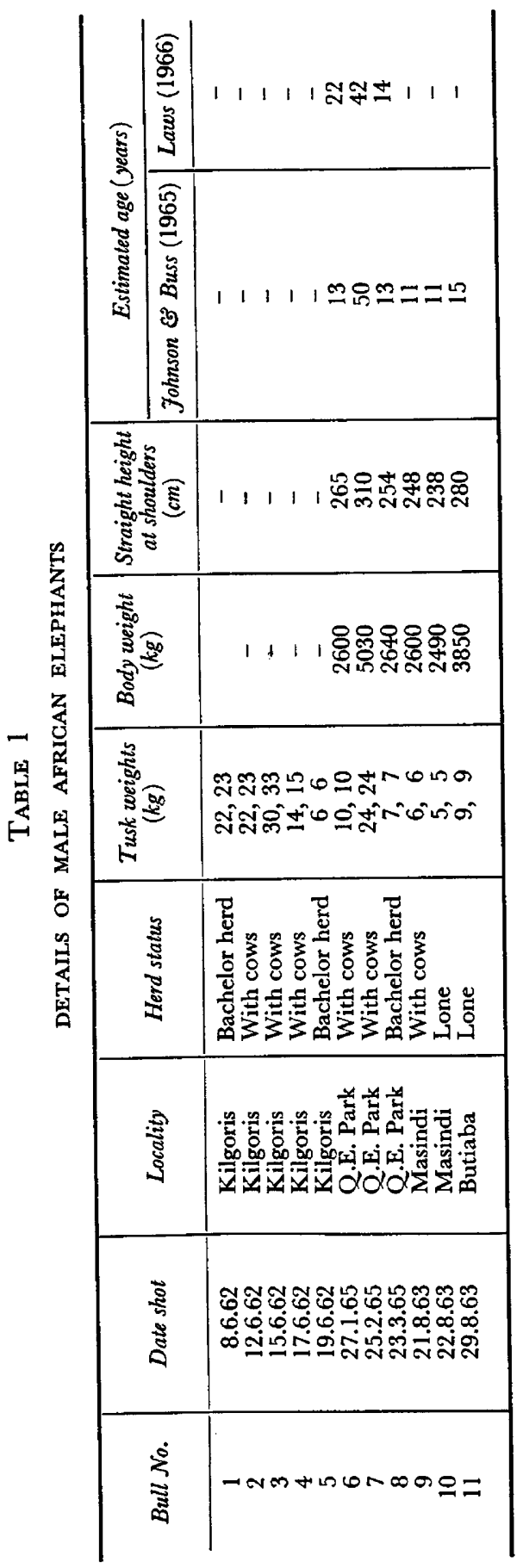


An attempt was also made to define the herd status of all the animals that were shot. The following three categories were recognized: (1) lone bulls, living by themselves, (2) bachelor bulls, living with a group of other bulls, and (3) bulls associated with herds of cows and calves. These details are also included in Table 1; it will be appreciated that it was never possible to tell for how long before death an animal's behaviour had conformed to one or other of these three patterns.

In addition to macroscopic dissections, a number of tissues were preserved for histological examination in $10 \%$ formol saline. They were processed in Cambridge within 1 to 6 months of the date of collection.

Material for biochemical studies was frozen immediately after it was taken from the animal. An 'Electrolux C80' gas-operated deep-freeze capable of maintaining a temperature of about $-15^{\circ} \mathrm{C}$ was kept at the base camp; a number of 'Freezella' bags were placed in it overnight, and then transferred to a large thermos flask, which was carried by the hunting party. Small pieces of tissue placed in close contact with the bags soon froze, and could be kept frozen until return to the base camp. All the samples were eventually packed in dry ice and flown to England.

\section{Body temperature measurements}

METHODS

These were carried out on seven bulls and two cows, immediately after death. In every instance a deep muscle temperature was taken, in the region of the triceps. For some animals a thermistor thermometer (Grant Instruments Ltd, Cambridge) was used, and for others a conventional mercury-glass thermometer. Repeated measurements were sometimes taken for up to $1 \mathrm{hr}$ after death, but the temperature seldom varied by more than $0.1^{\circ} \mathrm{C}$. The thermistor thermometer was re-calibrated each day against a standard mercury thermometer.

\section{Testes}

Histology. Sections of formalin-fixed testicular tissue embedded in paraffin wax were cut at $6 \mu$ and stained with haematoxylin and chromotrope. Mean diameters of the seminiferous tubules were determined by means of a calibrated micrometer eyepiece.

Testosterone determinations. These were performed according to the procedure of Short \& Mann (1966), the final estimation of the testosterone acetate being carried out by ultraviolet spectroscopy or gas chromatography, depending on the amount of steroid present.

In order to confirm the identity of the testosterone acetate, the pooled eluates from the paper chromatograms of bulls Nos. 1 to 5 were saponified with $0.5 \mathrm{ml} 0.1 \mathrm{~N}-\mathrm{NaOH}$ for $1 \mathrm{hr}$ at room temperature, rechromatographed and the free testosterone eluted. It was then oxidized to androstenedione by overnight treatment with a few drops of a $10 \%(\mathrm{w} / \mathrm{v})$ solution of chromium trioxide in pyridine. The reaction product was re-chromatographed in a ligroin $/ 80 \%$ methanol paper system, and was shown to have the same $\mathbf{R}_{\mathbf{f}}$ value as authentic androstenedione. After elution, the infra-red absorption 
spectrum in $\mathrm{KBr}$ was determined in a Unicam S.P. 200 infra-red spectrophotometer. It was identical in every respect with that of authentic androstenedione.

\section{Male accessory organs}

Histology. Sections of formalin-fixed tissues were embedded in paraffin wax, cut at 6 to $8 \mu$, and stained with haematoxylin and chromotrope, and by the periodic acid-Schiff (PAs) procedure.

Chemical analyses. Carbohydrates were identified by paper chromatography. Two 50-ml samples of seminal vesicle secretion from elephants Nos. 2 and 3 were precipitated with $3.5 \mathrm{vol}$. ethanol and, after centrifugation and filtration, the clear extracts were concentrated to about $1 \mathrm{ml}$. They were then applied to mixed columns of Dowex AG-1 (OAc $\left.{ }^{-}\right)$and Amberlite IR-120 ( $\left.\mathrm{H}^{+}\right)$; the column eluates were concentrated to about $1 \mathrm{ml}$, and 1 to $5 \mu \mathrm{l}$ quantities were taken for chromatography on paper at $25^{\circ} \mathrm{C}$ in ethyl acetate-pyridinewater $(8: 2: 1)$ using various pure sugars as markers. Twenty-four hours later the paper chromatograms were dried and treated with ammoniacal silver nitrate (Trevelyan, Procter \& Harrison, 1950), so as to identify the silverreducing areas. In addition, fructose was also identified by the yeast fermentation test (Mann, 1946).

Quantitative determinations. The quantitative determination of fructose was carried out by a colorimetric method (Mann, 1948). Ergothioneine was determined by the method of Hunter (1951), as adapted to semen by Mann, Short, Walton, Archer \& Miller (1957). Citric acid was determined in extracts prepared by de-proteinization with trichloracetic acid, according to the procedure of Speck, Moulder \& Evans (1946), as adapted to male reproductive organs by Lindner \& Mann (1960). Sialic acid was determined by the method of Warren (1959), using $\mathcal{N}$-acetylneuraminic acid as the standard.

\section{RESULTS}

\section{General considerations}

Text-figure 1 summarizes in diagrammatic form the principal anatomical features of the male elephant's reproductive tract, as found in the present study.

\section{Body temperature}

The body temperatures of seven male elephants (Nos. 2 to 8) and two females (Nos. 12 and 13) are shown in Table 2, together with details of the climatic conditions at the time of death. The mean temperature was $36.8^{\circ} \mathrm{C}$, with a range from $36 \cdot 2^{\circ}$ to $37.5^{\circ} \mathrm{C}$. It is probable that the deep body temperature taken in this way is higher than the rectal temperature; in the case of bull No. 6 , the deep body and rectal temperatures taken at the same time were $37.0^{\circ}$ and $36.5^{\circ} \mathrm{C}$ respectively. The corresponding figures for bull No. 7 were $37.5^{\circ}$ and $36.5^{\circ} \mathrm{C}$. One animal, an adult cow, was excluded from this study; $1 \mathrm{hr}$ after death it had a deep muscle temperature of $38.1^{\circ} \mathrm{C}$, but $\frac{1}{2} \mathrm{hr}$ later this had fallen to $36.8^{\circ} \mathrm{C}$. This high initial temperature was probably due to the fact that the animal had thrashed around on the ground for some minutes before eventually dying. 
Testes

The left and right testes of the African elephant are located intra-abdominally, in the lumbar region, medial and slightly posterior to the kidneys (see Pl. 1, Fig. 1). They are loosely suspended from the dorsal body-wall by a fold of peritoneum and connective tissue, the mesorchium, which allows considerable movement. When incised, the testicular tissue bulges from the surrounding tunics, and has a characteristic brown, pulpy appearance. There is a central

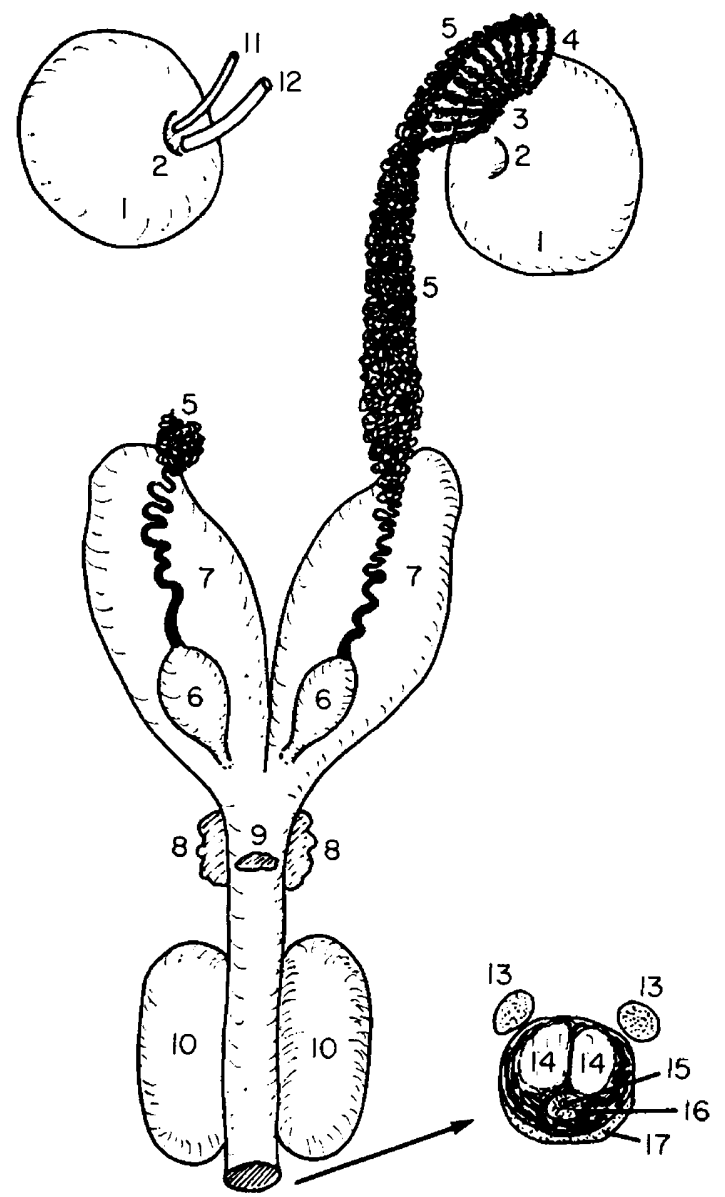

TeXr-FIG. 1. Diagrammatic representation of the reproductive tract of the male African elephant, ventral view

Key: 1 , testis; 2 , hilus of testis; 3 and 4 , ductuli efferentes; 5 , wolffian duct; 6 , ampulla of the wolffian duct; 7 , seminal vesicle; 8 , prostate; 9 , neck of bladder (cut); 10, bulbourethral gland; 11, spermatic artery; 12, branch of spermatic vein draining the substance of the testis; 13, levator penis muscle; 14 , corpus cavernosum penis; 15, urethra; 16, corpus cavernosum urethrae; 17 , bulbocavernosus muscle.

core of connective tissue, with septa radiating out in all directions (see Pl. 1, Fig. 2). The testis of elephant No. 1 was $17 \mathrm{~cm}$ long and $15 \mathrm{~cm}$ wide. The testis of the full-term male foetus was $4.5 \mathrm{~cm}$ long and $3.5 \mathrm{~cm}$ wide. The left and right testes of bulls Nos. 6,7 and 8 weighed respectively 1590, 1360;2950, $3180 ; 800$ and $850 \mathrm{~g}$. 
The blood supply to the left testis was investigated in five adult bulls (Nos. 2, $3,6,7$ and 8 ) and in the full-term foetus. The spermatic artery, which arises from the renal artery, runs a short, straight course in the mesorchium directly into the hilus of the testis. The spermatic vein, which in the adult is about $2.5 \mathrm{~cm}$ in diameter, emerges from the hilus as a single, large vessel. About $5 \mathrm{~cm}$ away from the testis it is joined by one or two other large veins draining the surface of the testis beneath the tunica albuginea. The common spermatic vein then runs directly into the left renal vein. The most characteristic feature of the vascular supply is the complete absence of a pampiniform plexus. There is also no cremaster muscle in the mesorchium, and no inguinal canal.

TABLE 2

DEEP BODY TEMPERATURES OF ELEPHANTS TAKEN IMMEDIATELY AFTER DEATH

\begin{tabular}{|c|c|c|c|}
\hline $\begin{array}{l}\text { Animal } \\
\text { No. }\end{array}$ & Sex & Body temperature $\left({ }^{\circ} \mathrm{C}\right)$ & Environmental details \\
\hline 2 & Male & $37 \cdot 0$ & 12.53 hours. Animal had been standing in the sun, \\
\hline 3 & Male & $36 \cdot 2$ & $\begin{array}{l}12.21 \text { hours. Animal had been lying down asleep in } \\
\text { thick forest on a cool, covercast day }\end{array}$ \\
\hline 4 & Male & $36 \cdot 6$ & $\begin{array}{l}12.39 \text { hours. Animal had been standing in a forest, } \\
\text { feeding, on a hot sunny day }\end{array}$ \\
\hline 5 & Male & $36 \cdot 6$ & $\begin{array}{l}15.03 \text { hours. Animal had been feeding in thick cover } \\
\text { on a cool overcast day }\end{array}$ \\
\hline 6 & Male & $37 \cdot 0$ & $\begin{array}{l}08.50 \text { hours. Animal had been followed for } 20 \mathrm{~min} \text {, } \\
\text { and was agitated }\end{array}$ \\
\hline 7 & Male & $37 \cdot 5$ & $\begin{array}{l}07.20 \text { hours. Animal had been walking back from } \\
\text { night feeding grounds; air temperature in shade }\end{array}$ \\
\hline 8 & Male & $37 \cdot 4$ & $\begin{array}{l}08.46 \text { hours. Animal had been chased for } \frac{3}{4} \mathrm{hr} \text {; air } \\
\text { temperature in shade } 26.0^{\circ} \mathrm{C}\end{array}$ \\
\hline 12 & Female & $36 \cdot 5$ & $\begin{array}{l}07.50 \text { hours. Animal standing in thick cover on a } \\
\text { cool, misty morning }\end{array}$ \\
\hline 13 & Female & $36 \cdot 8$ & $\begin{array}{l}07.55 \text { hours. Animal was excited and had bee } \mathrm{n} \text { run- } \\
\text { ning; cool misty morning }\end{array}$ \\
\hline
\end{tabular}

Numerous large lymphatic vessels up to $1 \mathrm{~cm}$ in diameter drain the testis, and haemal lymph nodes are present in the mesorchium. The spermatic nerve is conspicuous, running posteriorly to the artery and vein.

The testes of eleven adult bulls were examined histologically, and they all showed signs of spermatogenesis. The mean diameters of the seminiferous tubules are shown in Table 3 , and it is interesting to note that in these animals tubular diameter appeared to be related to age: for example, the youngest animal, No. 10, had the smallest tubules, whereas one of the oldest animals, No. 3, had the largest.

There also appeared to be considerable variations in the number of Leydig cells present. In animals Nos. 2, 3 and 4 the interstitial tissue was particularly well developed; the differences between two animals of similar age are illustrated in Pl. 1, Figs. 3 and 4. The Leydig cells themselves conform to the classical descriptions of this cell type, being large and polyhedral with homogeneous cytoplasm and a centrally placed vesicular nucleus.

The concentrations of testosterone in the testes of all eleven elephants are shown in Table 3, the results having been corrected for extraction losses. 
The variations in concentration are extreme, ranging from 3 to $490 \mu \mathrm{g} / 100 \mathrm{~g}$ testicular tissue. The concentration does not seem to be related to the mean tubular diameter, the age of the animal, the time of the year or the behavioural status. However, it may be significant that the three animals with the largest amounts of interstitial tissue (Nos. 2, 3 and 4) also had the highest testosterone concentrations.

Androstenedione was not detected in significant amounts in any of the testes examined.

\section{The ductuli efferentes and wolffian duct}

In most mammals the anatomical distinction between the epididymis and the ductus deferens is an obvious one, but this is not the case in the elephant. Until more information is available on the precise boundaries of the ductuli efferentes, ductus epididymidis and ductus deferens in the elephant, we propose to divide the excurrent duct into two parts-the ductuli efferentes and the wolffian duct.

TABLE 3

DIAMETERS OF ELEPHANT SEMINIFEROUS TUBULES, AND TESTICULAR TESTOSTERONE CONCENTRATIONS, CORRECTED FOR EXTRACTION LOSSES

\begin{tabular}{c|c|c}
\hline Bull No. & $\begin{array}{c}\text { Mean tubular diameter }(\mu) \\
\pm \text { Standard error of mean }\end{array}$ & $\begin{array}{c}\text { Testicular testosterone } \\
\text { concentration }(\mu \mathrm{g} / 100 \mathrm{~g})\end{array}$ \\
\cline { 2 - 3 } & $206 \pm 3$ & 9 \\
2 & $224 \pm 3$ & 152 \\
3 & $232 \pm 4$ & 490 \\
4 & $202 \pm 3$ & 176 \\
5 & $161 \pm 3$ & 8 \\
6 & $167 \pm 2$ & 81 \\
7 & $223 \pm 3$ & 3 \\
8 & $145 \pm 3$ & 92 \\
9 & $137 \pm 2$ & 139 \\
10 & $124 \pm 2$ & 123 \\
11 & $127 \pm 3$ & 123 \\
\hline
\end{tabular}

The ductuli efferentes leave the antero-medial aspect of the testis, just in front of the hilus. It is extremely difficult to locate this region in the adult animal, since it is embedded in the fat and connective tissue of the mesorchium. The ductuli consist of about twelve highly convoluted tubules, about $0.5 \mathrm{~mm}$ in diameter, radiating out in a fan-like structure from the medial aspect of the testis (see Pl. 2, Fig. 1). Histological examination has shown them to be lined by a tall, pseudo-stratified ciliated columnar epithelium, and to be filled with spermatozoa (see Pl. 2, Fig. 2). The ductuli efferentes join the wolffian duct at right angles.

The wolffian duct is a much larger structure than the ductuli efferentes, being about $1 \mathrm{~mm}$ in diameter initially, and extensively coiled throughout almost the whole of its overall length of about $160 \mathrm{~cm}$ (see Pl. 2, Fig. 2). The diameter increases slowly to about $5 \mathrm{~mm}$ in the middle section, but in the last few centimetres of the duct it increases quite rapidly to a centimetre or more; the 
number of convolutions diminishes as the duct approaches the seminal vesicle (P1. 1, Fig. 2). In the mid-portion of the duct, the convolutions form a structure that may be up to $5 \mathrm{~cm}$ in cross-sectional diameter, which gives some idea of the complexity of the coiling.

The wolffian duct leaves the medial aspect of the testis and runs posteriorly in a fold of mesentery, medial to the ureter, which it never crosses (see Pl. 1, Fig. 1). For the last few centimetres of its length, when it is relatively straight, it runs ventral to the seminal vesicle and dorsal to the bladder, before opening into the ampulla.

Histological examination has shown that the anterior end of the wolffian duct has a high columnar ciliated epithelium with basally situated round nuclei. The epithelium is raised in slight folds, and the lumen of the tubule contains spermatozoa (Pl. 2, Fig. 2); there is little smooth muscle present. In the caudal part of this segment, the height of the epithelium is gradually reduced, and the folds become less conspicuous.

In the middle of the wolffian duct, the epithelium has once again become extremely folded, giving the appearance of numerous 'villi'. At the base of each of these folds the epithelium is ciliated and low columnar in type. However, at the apex of the folds it is cuboidal, and there are very few cilia to be seen. The lumen still contains numerous spermatozoa, but the most striking feature is an extremely vascular area at the apex of the epithelial folds. The capillaries in this area are so dilated that they give the folds a vacuolated appearance. There is now a well-developed coat of circular smooth muscle.

The terminal portion of the duct is somewhat similar in appearance to the mid part, except that it is now invested by an even thicker smooth muscle coat, and the lumen has enlarged. The epithelium is still extensively folded, and at the base of the folds it is low columnar and ciliated. Cilia are apparently absent from the apices of the folds, where the epithelium is cuboidal. The vascularity in this area is even more pronounced than it was in the mid portion of the duct (see Pl. 2, Fig. 3).

The fluid contents were obtained from the lower regions of the wolffian duct in elephants Nos. 2, 3 and 4. Fructose was present in all three samples in concentrations of 17,2 and $14 \mathrm{mg} / 100 \mathrm{ml}$ (see Table 4).

\section{Ampulla}

After passing ventral to the seminal vesicles, the wolffian duct opens by means of a small pink papilla into an ampulla. In bull No. 4, one of the ampullae was $8 \mathrm{~cm}$ long and $6 \mathrm{~cm}$ wide; in bull No. 7, the right and left ampullae, emptied of secretion, weighed 53 and $52 \mathrm{~g}$ respectively. The contents of the ampullae were examined in bulls Nos. 2 to 8. In animals 2, 3 and 8 there was no visible secretion present, but in all the other animals a white, watery secretion full of spermatozoa was present.

The ampullae lie ventral to the seminal vesicles, and open into the ducts of the seminal vesicles to form two common ejaculatory ducts. The opening of the ampulla into the ejaculatory duct is large enough to admit one finger, and in life it is probably kept closed by a flap-like prolongation of the floor of the seminal vesicle. However, it seems likely that there had been some reflux of 
vesicular secretion into the ampullae in some of the animals in this study.

Histological sections were prepared from the ampullae of elephants Nos. 3 and 4 . The ampulla is a very muscular organ, as is the terminal portion of the wolffian duct; there is a great deal of circular and longitudinal muscle in its walls. But in contrast to the wolffian duct, the ampulla is also a glandular organ. It is lined by a single layer of epithelial cells and has numerous simple tubular glands, many of them being distended by large eosinophilic bodies with a homogeneous matrix, that have apparently been laid down in concentric rings. The glandular epithelium varies from cuboidal to columnar, and numerous spermatozoa were seen lying free in the lumen of the glands, even in elephant No. 3 whose ampullae contained no visible secretion at the time of death.

TABLE 4

CONCENTRATIONS OF FRUCTOSE AND CITRIG ACID IN ELEPHANT MALE ACCESSORY SECRETIONS

\begin{tabular}{c|l|c|c}
\hline Bull No. & Secretion & $\begin{array}{c}\text { Fructose } \\
(\mathrm{mg} / 100 \mathrm{ml})\end{array}$ & $\begin{array}{c}\text { Citric acid } \\
(\mathrm{mg} / 100 \mathrm{ml})\end{array}$ \\
\hline \multirow{2}{*}{1} & Vesicular & 57 & 0 \\
& Prostatic & 67 & 0 \\
3 & Vesicular & 55 & 0 \\
3 & Wolffian duct & 17 & 0 \\
& Vesicular & 62 & $0 \cdot 4$ \\
& Bulbo-urethral & 1 & $5 \cdot 0$ \\
4 & Wolffian duct & 2 & 0 \\
4 & Prostatic & 7 & $5 \cdot 9$ \\
& Vesicular & 66 & 0 \\
5 & Ampullar & 5 & - \\
6 & Wolffian duct & 14 & $0 \cdot 8$ \\
7 & Vesicular & 35 & $0 \cdot 7$ \\
& Vesicular & 95 & 0 \\
& Ampullar & 150 & 0 \\
& Normal vesicular & 147 & $1 \cdot 4$ \\
\hline
\end{tabular}

Chemical analyses of the ampullary secretion of elephant No. 4 revealed the presence of a small amount of fructose, whereas in the case of elephant No. 7 the fructose concentration was extremely high and similar to that of the vesicular secretion (see Table 4). The possibility cannot be excluded that in bull No. 7 there had been a considerable reflux of vesicular secretion into the ampulla, possibly at the time of death.

\section{Seminal vesicles}

The seminal vesicles are large, oval, thick-walled sacs lying within the pelvic cavity. In some animals there was a slight protuberance on the anterior end of the organ (see Pl. 1, Fig. 2). The two seminal vesicles, minus their secretion, weighed $410 \mathrm{~g}$ in elephant No. 6, $954 \mathrm{~g}$ in elephant No. 7 and $414 \mathrm{~g}$ in elephant No. 8. Thus the oldest animal had the largest seminal vesicles. The mucosal lining of the seminal vesicles presented an unusual appearance, with high, irregular folds and numerous crater-like pits (see Pl. 2, Fig. 4). 
The vesicular secretion was clear and watery in most animals, although it did vary considerably between animals in volume, colour and consistency (see Table 5). These variations in volume may have been due to the method of shooting: animals Nos. 5 to 8 were all killed by brain shots, and certainly in the case of animals Nos. 7 and 8 the presence of spermatozoa in the bladder indicated that retrograde ejaculation had occurred, probably at the time of death. The marked difference in the colour of the secretion from the right and left seminal vesicle of elephant No. 7 was apparently due to the presence of a large melanoma in the wall of the right gland. The diagnosis of a melanoma was confirmed histologically.

Histological examination showed that the seminal vesicles are invested by a thick layer of smooth muscle, and the glandular tissue is interspersed amongst some of these muscle fibres. The glandular epithelium is pseudo-stratified and

TABLE 5

VOLUME AND NATURE OF ELEPHANT VESICULAR SECRETIONS

\begin{tabular}{c|c|l}
\hline Bull No. & $\begin{array}{c}\text { Volume of secretion/ } \\
\text { seminal vesicle }(\mathrm{ml})\end{array}$ & \multicolumn{1}{|c}{$\begin{array}{c}\text { Description of } \\
\text { secretion }\end{array}$} \\
\hline 1 & 50 & Clear, watery, pale grey \\
2 & 300 & Clear, watery, pale grey \\
3 & 325 & Clear, watery, pale grey \\
4 & 300 & Clear, watery, pale grey \\
5 & 50 & Watery, dark grey \\
6 & 12 & Viscous, dark brown \\
7 & Right 25 & Watery, dark grey \\
8 & Left 90 & Clear, watery \\
\hline
\end{tabular}

cuboidal in type, and many intra-cellular vacuoles are present. A number of homogeneous bodies were seen lying free in the lumina of the glands; these did not appear to have the same concentric composition as those in the ampullae.

Chemical analyses showed that the vesicular secretions of animals Nos. 1 to 7 contained fructose as a major constituent. As can be seen from Table 4, the concentrations ranged from 35 to $147 \mathrm{mg} / 100 \mathrm{ml}$ fluid. In two animals (Nos. 2 and 3) the vesicular secretion was also examined chromatographically for the presence of silver-reducing carbohydrates. In addition to the expected large quantity of fructose, small amounts of several other silver-reducing compounds were detected. One of these behaved chromatographically as inositol, and another ran in a position corresponding to sorbitol (between galactose and glucose). The seminal vesicle secretion of all seven elephants contained very little citric acid, and the ergothioneine content of the secretions from animals Nos. 1, 2, 5, 6 and 7 was negligible. Sialic acid was detected at a concentration of $0.006 \mathrm{~m}$-moles $/ 100 \mathrm{ml}$ in elephant No. 5 .

\section{Prostate}

The prostate is situated on the dorsal wall of the urethra, immediately 
posterior to the seminal vesicles (see Pl. 1, Fig. 2). Its appearance varied considerably between animals. The simplest arrangement, as seen in elephants Nos. 3 and 8, was in the form of two discrete lobes, one on either side of the urethra. In animal No. 3, one lobe was noticeably larger than the other and contained $15 \mathrm{ml}$ of secretion. This was presumably some type of retention cyst, since it was impossible to obtain more than a few drops of secretion from any of the other seven prostates that were examined. In some animals, e.g. Nos. 2 and 7, the left and right lobes of the prostate appeared to be subdivided into a number of lobules.

Histologically, the prostate can be seen to be covered by a thick layer of smooth muscle. The glandular tissue beneath this muscular capsule is tubuloalveolar in type, the cells themselves being columnar, with basal nuclei.

As can be seen from Table 4, fructose was detected in the prostatic secretions of elephants Nos. 1 and 3. In elephant No. 1 the concentration was particularly high; however, the volume of the secretion was too small to permit a rigorous chemical identification of the sugar. It is also possible that in view of the small volume of vesicular secretion (see Table 5), this animal had ejaculated at the moment of death, and contaminated the prostatic secretion with some vesicular secretion. The fluid from the cystic prostate in elephant No. 3 contained very little fructose, but an appreciable amount of citric acid $(5.9 \mathrm{mg} / 100 \mathrm{ml})$ and sialic acid $(0.022 \mathrm{~m}$-moles $/ 100 \mathrm{ml})$.

\section{Bulbo-urethral glands}

The bulbo-urethral glands were studied in detail only in elephant No. 3. The two glands lie close together on the dorsolateral aspect of the urethra close to the ischial arch. Each is covered by a thick muscular coat, and on cutting into the substance of one gland it was possible to collect about $100 \mathrm{ml}$ of a clear, viscous, extremely tenacious secretion. This contained a small amount of citric acid, but little or no fructose (see Table 4). Sialic acid was present in a concentration of $0.003 \mathrm{~m}$-moles $/ 100 \mathrm{ml}$.

The histological appearance of the bulbo-urethral gland, which is tubuloalveolar in type, is shown in Pl. 3, Fig. 1. The stroma contains smooth muscle fibres. The alveoli vary very much in size within a single gland, and the glandular epithelium stains strongly with the PAs procedure.

\section{Penis}

The penis was dissected in bull No. 3, and the glans examined in bull No. 4 . Cut in cross-section just below the ischial arch, the large paired levator penis muscles lay anteriorly. There was an extremely well developed corpus cavernosum penis divided into two halves by a thick septum. The urethra, surrounded by a relatively small corpus cavernosum urethrae, was caudal to the corpus cavernosum penis, and was surrounded on the outside by the bulbo-cavernosus muscle.

The free end of the penis and the prepuce conformed to the description given by Mojsisovics (1879) and Oudemans (1892); large areas of it are devoid of pigmentation. The opening of the urethra at the end of an ill-defined urethral process is $\mathrm{Y}$ shaped, the two arms of the $\mathrm{Y}$ being situated dorsally. 


\section{Temporal gland}

In view of the alleged relationship between temporal gland secretion, 'musth' and sexual activity in the male Indian elephant, it seemed important to examine the temporal gland in some detail in both male and female African elephants.

The gland is situated in the temporal fossa, and opens to the surface by means of a duct in the centre of its lower border. Some bulls (Nos. 2 and 4) showed a pronounced secretion from the temporal gland at the time of death (see Pl. 3, Fig. 2), whereas others (Nos. 1, 6, 7 and 8) had no visible secretion. The fact that the gland was not secreting in elephants Nos. 6, 7 and 8, which had the highest body temperatures of any of the animals studied, suggests that the temporal gland does not function like a sweat gland.

One of the temporal glands was dissected out and weighed in six bulls and four cows, and the results are shown in Table 6 . There is considerable individual

TABLE 6

TEMPORAL GLAND WEIGHTS OF AFRICAN ELEPHANTS

\begin{tabular}{|c|c|c|c|c|}
\hline \multirow{2}{*}{ Animal $\mathcal{N o}$} & \multirow{2}{*}{ Sex } & \multicolumn{2}{|c|}{ Estimated age (years) } & \multirow{2}{*}{$\begin{array}{l}\text { Weight of one } \\
\text { temporal gland }(\mathrm{g})\end{array}$} \\
\hline & & Johnson $\mathcal{F}^{2}$ Buss (1965) & Laws (1966) & \\
\hline $\begin{array}{r}6 \\
7 \\
8 \\
9 \\
10 \\
11 \\
14 \\
15 \\
16 \\
17\end{array}$ & $\begin{array}{l}\text { Male } \\
\text { Male } \\
\text { Male } \\
\text { Male } \\
\text { Male } \\
\text { Male } \\
\text { Female } \\
\text { Female } \\
\text { Female } \\
\text { Female }\end{array}$ & $\begin{array}{l}13 \\
50 \\
13 \\
11 \\
11 \\
15 \\
14 \\
15 \\
12 \\
12\end{array}$ & $\begin{array}{l}22 \\
42 \\
14 \\
- \\
- \\
- \\
38 \\
20 \\
- \\
-\end{array}$ & $\begin{array}{r}440 \\
1590 \\
380 \\
900 \\
230 \\
740 \\
875 \\
495 \\
700 \\
600\end{array}$ \\
\hline
\end{tabular}

variation and no obvious difference between the sexes. It may be significant that the oldest animal had the largest gland.

The secretion of the temporal gland is serous in nature, and smells extremely strongly of elephant. It was never possible to squeeze more than about $1 \mathrm{ml}$ of secretion out of any of the glands, regardless of their secretory state during life.

On macroscopic examination, the temporal gland (see Pl. 3, Fig. 3) looks like salivary tissue, being divided up into numerous lobules by connective tissue septa. The duct of the gland is rough and keratinized, and often contains a stick or a collection of hairs.

Histological examination of the temporal glands from more than twentyfive male and female elephants showed them to be apocrine in nature, with an epithelium that varied from low cuboidal to columnar, depending on the animal. Myo-epithelial cells surround the ducts and canaliculi. There was considerable variation between animals in the size of the glandular lumen and the amount of secretion present; however, none of these differences appeared to be related to sex or herd status.

Thus there was no evidence to suggest that the size or activity of the temporal glands was in any way related to reproductive activity. 
Spermatozoa

Spermatozoa were present in material recovered from the terminal portions of the wolffian duct of bulls Nos. 1 to 8, and from the ampullae of bulls Nos. 4, 5,6 and 7. This material was stored in polythene bottles at body temperature until it could be examined, the time elapsed since death of the animal varying from 2 to $6 \mathrm{hr}$. In none of the samples could a single motile spermatozoon be seen. However, on dilution with vesicular secretion, 1 to $15 \%$ of the spermatozoa developed good progressive motility in elephants Nos. 2, 3, 4 and 7. No motility could be induced in the spermatozoa from animals Nos. 6 or 8 .

Spermatozoa were also found in urine from the bladder of bulls Nos. 7 and 8 . In the case of bull No. 7, where the examination was not carried out until $6 \mathrm{hr}$ after death, many spermatozoa were motile. In bull No. 8, none of the spermatozoa recovered from the bladder was motile.

A drop of the wolffian duct contents from bulls Nos. 1 to 8 , and a drop of the ampullary contents from bulls Nos. 4, 5 and 7 were treated with the eosinnigrosin stain (Campbell, Dott \& Glover, 1956), and the mixture allowed to stand for about $5 \mathrm{~min}$ before making a smear. By this means it was hoped to be able to assess the proportion of 'live' (unstained) and 'dead' (stained) spermatozoa. From the results shown in Table 7, it can be seen that the

\begin{tabular}{l} 
TABLE 7 \\
PERCENTAGE OF 'LIVE' SPERMATOZOA AS \\
JUDGED BY EOSIN-NIGROSIN STAINING, IN \\
THE ELEPHANT REPRODUCTIVE TRACT \\
\hline \\
\hline
\end{tabular}

percentage of 'live' spermatozoa in the wolffian duct was very high, but that many more 'dead' spermatozoa were present in the ampullae. Morphologically, elephant spermatozoa resemble those of the horse, both in size and shape (P1. 3, Fig. 4).

\section{DISGUSSION}

In gross morphological appearance, the male reproductive tract of the African elephant, Loxodonta africana, is similar to that of the Indian elephant, Elephas maximus.

The elephant differs from most other mammals in having no obvious epididymis, and neither the descriptions given by Eales (1929) nor Schulte (1937) do justice to this fact, or to the great complexity of the wolffian duct.

In his detailed monograph on the anatomy of the excurrent ducts of the 
testis, Benoit (1926) showed that in man, dog, cat, boar, ram, bull and stallion the caput epididymidis is composed almost entirely of the convoluted ductili efferentes. Each joins the single ductus epididymidis at right angles, a situation that is similar to that in the elephant. But since there do not seem to be any clear-cut histological distinctions between the ductus epididymidis and the ductus deferens in other species (Nicander, 1957a, b), we have preferred not to use these two terms with respect to the elephant, where the distinction between them must be purely arbitrary. We have therefore restricted our remarks to the ductuli efferentes and the wolffian duct, recognizing that the latter includes both the ductus epididymidis and the ductus deferens.

Spermatozoa freshly recovered from the cauda epididymidis or ductus deferens of most domestic animals are motile when exposed to air (Walton, 1956; Dott, 1958). The failure to find motile spermatozoa in the wolffian duct or ampulla of any of the elephants in the present study, and the fact that some motility could be induced by diluting the spermatozoa with vesicular secretion, are matters of some interest, and deserve further study. On the other hand, motile spermatozoa were found in urine from the bladder. This is in accord with a similar observation made by Schulte (1937) who found motile spermatozoa in the bladder $12 \mathrm{hr}$ after the death of an Indian elephant.

If it were possible to dissect out the highly convoluted wolffian duct there is no doubt that it would measure several hundred metres in length; it must contain a vast store of spermatozoa. The histological appearance of the caudal half of the duct is quite unlike that of other mammals (Benoit, 1926), and may be related to the need to store immotile spermatozoa for long periods at body temperature. The epithelium is raised into numerous longitudinal folds, and the tips of these folds contain a network of large blood vessels which are presumably necessary for providing nutrients to and removing waste products from the stored spermatozoa.

Another peculiar feature concerns the musculature of the penis. The two large, dorsally situated levator penis muscles (Compressor venae dorsalis penis muscles of Eales, 1929) unite to form a common tendon which inserts on the dorsum of the corpus cavernosum penis (Gulliver, 1847; Watson, 1872; Plateau \& Liénard, 1881; Schulte, 1937). It is this muscle which probably accounts for the S-shaped flexure of the penis at erection, as noted by Slade (1903) and Short (1966). Presumably the male hooks the upwardly flexed tip of his penis into the ventrally situated vulva of the female, and she then retracts it caudally and dorsally, using the powerfully developed levator clitoris muscles. The male can then insert the full length of his penis into the female.

The phenomenon of musth in the male Indian elephant has often been likened to the rutting of seasonally breeding animals, such as deer. However, since male Indian elephants frequently mate when not in musth (Slade, 1903; Hundley, 1922; Wilson, 1922; Ferrier, 1948; McGaughey, 1963), it seems clear that musth is not necessarily related to sexual activity.

Nobody has ever described musth in the African elephant, possibly because the animal has not often been domesticated. One of the objectives of the present study was to discover whether there is any evidence for the occurrence of cyclical reproductive activity in the African elephant either with respect to 
spermatogenic or androgenic activity. Johnson (1963) and Johnson \& Buss (1967) have carried out a detailed analysis of testicular morphology in a number of African elephants, and concluded that there was no cessation of spermatogenesis after puberty; however, Buss \& Johnson (1967) claimed that there was a cyclical variation in Leydig cell function which probably determined behavioural status.

Whilst it is a relatively simple matter to determine the reproductive status of a female elephant by inspection of the uterus and ovaries at post-mortem (Perry, 1953; Short \& Buss, 1965; Short, 1966; Buss \& Smith, 1966), the definition of the reproductive status of the male elephant presents a number of difficulties. It is easy to see whether or not the animal has attained puberty merely by looking for spermatozoa. But if one wishes to look for differences in the degree of androgenic or spermatogenic activity between individuals, this is much more difficult. Most of the organs of the elephant continue to grow throughout life, and parameters such as the mean diameter of the seminiferous tubules or the weight of testes and seminal vesicles also probably increase with age, thus obscuring any seasonal changes that might occur. Furthermore, when an elephant is killed, particularly by a brain shot, there is always the possibility that a retrograde ejaculation might occur. This might invalidate any conclusions as to the androgenic state of the animal which were based on the volume of the accessory secretions. It is interesting that the seminal vesicles produce fructose as a major constituent, as they do in the Indian elephant (unpublished observations). Finally, the elephant testis is such a large organ that it is impossible to obtain an overall picture either of its histological appearance or its steroid content by studying only a few grams of tissue.

In some of the elephants in the study, the concentrations of testicular testosterone were similar to those found in the bull. stallion, zebra, zebra-horse and zebra-donkey hybrids, and deer (Lindner \& Mann, 1960; King, Short, Mutton \& Hamerton, 1966; Short \& Mann, 1966). But in some elephants the testosterone concentrations were extraordinarily low, resembling the values found in the roebuck at a time of the year when its testes are androgenically inactive (Short \& Mann, 1966). In deer, spermatogenic and androgenic activity are closely related events, but in the elephant, we have found low testosterone values in animals with active spermatogenesis. From our limited data, it is impossible to decide whether or not the wide fluctuations in the testicular testosterone concentration of elephants represent cyclical changes in androgenic activity. In any case, these concentrations bear no obvious relation either to the season of the year, the behavioural status of the animal, or the fructose concentration in the vesicular secretion.

Buss \& Johnson (1967) have measured the testicular testosterone concentrations in thirty-two elephants; the values which they reported are on average a hundred times higher than those found in the present study.

In reviewing the status of mammals with intra-abdominal testes, Wislocki (1933) came to the conclusion that in general their body temperature is low, and that this may be the reason why spermatogenesis can continue unimpaired. The present study has demonstrated that the mean deep body temperature of the African elephant is $36.8^{\circ} \mathrm{C}$, and it can certainly rise to as high as $37.5^{\circ} \mathrm{C}$ 
on occasions. This seems to discount Wislocki's suggestion, and indicates instead that the elephant's testis is particularly resistant to temperature effects. It is worth noting that our values for body temperature are somewhat higher than the rectal temperatures of nine elephants in Uganda recorded by Buss \& Wallner (1965), who found a mean vaue of $36.4^{\circ} \mathrm{C}$, with a range of $36.0^{\circ}$ to $36.7^{\circ} \mathrm{C}$. This apparent discrepancy may be explained by our finding that the deep body temperature can be as much as $1^{\circ} \mathrm{G}$ higher than the rectal temperature, taken at the same time.

Benedict (1936) and Benedict \& Lee (1936) measured the urine and faeces temperatures of many Indian elephants in circuses in the United States. The mean urine temperature was $35.8^{\circ}$ to $35.9^{\circ} \mathrm{C}$, faeces temperatures being about $0.7^{\circ} \mathrm{C}$ higher. These values are also somewhat lower than ours, an effect which may be partly due to differences in environmental temperature. Bligh \& Harthoorn (1965) concluded that the elephant occupies a position intermediate between those animals with wide fluctuations in body temperature associated with water conservation, e.g. the camel, and those with a relatively constant body temperature, e.g. the hippopotamus.

One of the consequences of a permanently intra-abdominal testis is that testicular cooling mechanisms, such as the counter-current heat exchange mechanism in the pampiniform plexus (Harrison \& Weiner, 1949; Waites \& Moule, 1961), become redundant. It was therefore very interesting to note that the elephant has no vestige of a pampiniform plexus.

We have been unable to detect any sex difference in the weight or histological appearance of the temporal gland. It is an apocrine, tubulo-alveolar structure in both the Indian and African elephant (Fernando, Jayasinghe \& Panabokke, 1963; Schneider, 1956), and produces an odoriferous secretion. In the Indian elephant, the gland appears to increase in size in males before the onset of musth; musth is seldom observed in females (Ferrier, 1948; Fernando et al., 1963). The gland only seems to discharge if the animal is in musth, and then the copious secretion runs down the side of the face. In the African elephant, it is common to see animals of both sexes, and all ages, with discharging glands (Perry, 1953), whereas they do not necessarily discharge in either the male or female at coitus (Short, 1966). Pocock (1916) suggested that the temporal gland might function primarily as a scent gland. The recent observations of Lyne, Molyneux, Mykytowycz \& Parakkal (1964) and Mykytowycz (1965) on the chin gland of the rabbit may be relevant. This apocrine, tubulo-alveolar gland of the rabbit is similar in appearance to the temporal gland of the elephant, and is used for territory marking, particularly by males. The gland is much larger in bucks than in does, and regresses in size if the buck is castrated.

Our failure to demonstrate a sex difference in the size or structure of the temporal gland in the elephant may be related to behavioural differences. The elephant is a wide-ranging animal, with no need to mark out a territory. Furthermore, the society is matriarchal, being organized around family units of cows and their calves; bulls appear to play little part in determining herd structure, and the dominant animal in a herd is often an old cow. The secretions of the temporal gland may nevertheless be very important in determining 
herd movements, since elephants have very poor sight. The frequency with which sticks and other objects are found in the temporal duct also suggests that the animals may rub their heads on trees and branches to leave a scent.

\section{ACKNOWLEDGMENTS}

This study was made possible in the frrst place by the willing co-operation of the Kenya Game Department and the Uganda National Parks; we would like to express our very sincere thanks to A. M. Graham and I. A. Ross for shooting all the elephants in accordance with our wishes. Dr R. M. Laws, Director of the Nuffield Unit of Tropical Animal Ecology in Uganda, kindly placed the facilities of his laboratory at our disposal; the skinning, weighing and dissecting of the animals would not have been possible without such a willing band of African assistants.

We would also like to thank Dr I. O. Buss, Dr U. de V. Pienaar, D. M. Wise, N. Fairall and I. Parker for all the trouble they took to supply us with a number of frozen and formalin-fixed specimens, and J. Stansfield of Unicam Instruments Ltd for carrying out the infra-red analysis. Dr T. D. Glover kindly read the manuscript and made a number of helpful suggestions.

The work was financed by generous grants to one of us (R.V.S.) from the Nuffield Foundation and the Uganda National Parks.

\section{REFERENCES}

Benedict, F. G. (1936) The physiology of the elephant. Carnegie Institution of Washington.

Benedict, F. G. \& LeE, R. C. (1936) Studies on the body temperature of elephants. Proc. natn. Acad. Sci. 22, 405.

Benort, J. (1926) Recherches anatomiques, cytologiques et histophysiologiques sur les voies excrétrices du testicule, chez les mammifères. Archs Anat. Histol. Embryol. 5, 175.

Bligh, J. \& Harthoorn, A. M. (1965) Continuous radiotelemetric records of the deep body temperature of some unrestrained African mammals under near-natural conditions. F. Physiol., Lond. 176, 145.

Buss, I. O. \& Johnson, Q. W. (1967) Relationships of Leydig cell characteristics and intratesticular testosterone levels to sexual activity in the African Elephant. Anat. Rec. 157, 191.

Buss, I. O. \& SмIтH, N. S. (1966) Observations on reproduction and breeding behaviour of the African elephant. F. Wildl. Mgmt, 30, 375.

Buss, I. O. \& Wallner, A. (1965) Body temperature of the African elephant. F. Mammal. 46, 104.

Campeell, R. C., Dott, H. M. \& Glover, T. D. (1956) Nigrosin-eosin as a stain for differentiating live and dead spermatozoa. F. agric. Sci. 48, 1.

Dotr, H. M. (1958) Species differences in the metabolism of epididymal spermatozoa. Stud. Fert. 10, 73.

EALES, N. B. (1929) The anatomy of a foetal African elephant, Elephas africanus (Loxodonta africana). III. The contents of the thorax and the abdomen, and the skeleton. Trans. R. Soc. Edinb. 56, 203.

Fernando, S. D. A., Jayasinghe, J. B. \& Panabokke, R. G. (1963) A study of the temporal gland of an Asiatic elephant Elephas maximus. Ceylon vet. F. 11, 108.

Ferrier, A. J. (1948) The care and management of elephants in Burma. Steel Bros, London.

Gulliver, G. (1847) Note on the spermatozoa and on the elevator muscles of the penis of the Indian elephant. Proc. zool. Soc. Lond. 105.

HARRISON, R. G. \& WeINER, J. S. (1949) Vascular patterns of the mammalian testis and their functional significance. F. exp. Biol. 26, 304.

HundLey, G. (1922) The breeding of elephants in captivity. F. Bombay nat. Hist. Soc. 28, 537.

Hunter, G. (1951) On ergothioneine in blood and diazo-reacting substances in maize. Biochem. 7. 48, 265.

Johnson, O. W. (1963) Histological and quantitative characteristics of the testes, observations on the teeth and pituitary gland, and the possibility of reproductive cyclicity in the African elephant (Loxodonta africana). Ph.D. thesis, Washington State University. 
Johnson, O. W. \& Buss, I. O. (1965) Molariform teeth of male African elephant in relation to age, body dimensions, and growth. F. Mammal. 46, 373.

Jounson, O. W. \& Buss, I. O. (1967) The testis of the African elephant (Loxodonta africana). II. Development, puberty and weight. F. Reprod. Fert. 13, 23.

King, J. M., Short, R. V., Mutton, D. E. \& Hamerton, J. L. (1966) The reproductive physiology of male zebra-horse and zebra-donkey hybrids. Comparative Biology of Reproduction in Mammals, p. 511. Ed. I. W. Rowlands. Academic Press, London.

KüHME, W. (1963a) Ergänzende Beobachtungen an afrikanischen Elefanten (Loxodonta africana Blumenbach 1797) in Freighage. Z. Tierpsychol. 20, 66.

KüнME, W. (1963b) Ethology of the African elephant (Loxodonta africana Blumenbach 1797) in captivity. Int. Zoo $\mathrm{rb} .4,113$.

LAws, R. M. (1966) Age criteria for the African elephant, Loxodonta a. africana. E. Afr. Wildl.7. 4, 1.

LiNDNER, H. R. \& MANN, T. (1960) Relationship between the content of androgenic steroids in the testes and the secretory activity of the seminal vesicles in the bull. $\mathcal{F}$. Endocr. 21, 341.

Lyne, A. G., Molyneux, G. S., Mykytowycz, R. \& Parakkal, P. F. (1964) The development, structure and function of the submandibular cutaneous (chin) glands in the rabbit. Aust. F. Zool. $12,340$.

ManN, T. (1946) Studies on the metabolism of semen. 3. Fructose as a normal constituent of seminal plasma. Site of formation and function of fructose in semen. Biochem. 7. 40, 481.

Mann, T. (1948) Fructose content and fructolysis in semen. Practical application in the evaluation of semen quality. F. agric. Sci. 38, 323.

Mann, T., Short, R. V., Walton, A., Archer, R. K. \& Miller, W. C. (1957) The tail-end sample of stallion semen. . agric. Sci. 49, 301.

McGaughex, C. A. (1963) Musth. Ceylon vet. 7. 11, 105.

Mojsisovics, A. von (1879) Zur Kenntris der afrikanischen Elefanten. Arch. Naturgesch. 45, 56.

Myкyтоwycz, R. (1965) Further observations on the territorial function and histology of the submandibular cutaneous (chin) glands in the rabbit Oryctologus cuniculus (L.) Anim. Behav. 13, 400.

NicANDER, L. (1957a) On the regional histology and cytochemistry of the ductus epididymidis in rabbits. Acta neerl. Morph. 1, 99.

NICANDER, L. (1957b) Studies on the regional histology and cytochemistry of the ductus epididymidis in stallions, rams and bulls. Acta neerl. Morph. 1, 337.

Oudemans, J. T. (1892) Die accessorischen Geschlechtsdrüsen der Säugetiere. De Erven Loosjes, Harlem.

Perry, J. S. (1953) The reproduction of the African elephant, Loxodonta africana. Phil. Trans. R. Soc. B, 237, 93.

Perry, J. S. (1954) Some observations on the growth and tusk weight in male and female African elephants. Proc. zool. Soc. Lond. 124, 97.

Perit, G. (1924) Sur l'abouchement des canaux déférents et des vésicules seminales au verumontanum de l'éléphant. Bull. Mus. Hist. nat., Paris, 30, 441.

Plateau, M. F. \& Liénard, M. V. (1881) Observations sur l'anatomie de l'éléphant d'Afrique (Loxodonta africanus) adulte. Bull. Acad. r. Belg. Cl. Sci. 1, 250.

Pocock, R. I. (1916) Scent glands in mammals. Proc. zool. Soc. Lond. 2, 742.

SCHNEIDER, R. (1956) Untersuchungen über den Feinbau der Schläfendrüse beim afrikanischen und indischen Elefanten, Loxodonta africana Cuvier und Elephas maximus Linnacus. Acta anat. 28, 303.

Schulte, T. L. (1937) The genito-urinary system of the Elephas indicus male. Am. F. Anat. 61, 131.

Shimizu, Y., Fujita, T., Kamiya, T. \& Isokawa, S. (1960) Anatomy of a female Indian elephant with special reference to its visceral organs. Acta anat. nippon. 35, 261.

Short, R. V. (1966) Oestrous behaviour, ovulation and the formation of the corpus luteum in the African elephant, Loxodonta africana. E. Afr. Wildl. F. 4, 56.

SHort, R. V. \& Buss, I. O. (1965) Biochemical and histological observations on the corpora lutea of the African elephant, Loxodonta africana. J. Reprod. Fert. 9, 61.

Short, R. V. \& MANN, T. (1966) The sexual cycle of a seasonally breeding mammal, the roebuck (Capreolus capreolus). F. Reprod. Fert. 12, 337.

Slade, H. (1903) On the mode of copulation of the Indian elephant. Proc. zool. Soc. Lond. p. 111.

Smith, J. A. \& Ross, W. D. (Eds) (1910) Historia Animalium. The Works of Aristotle. Vol. IV. Clarendon Press, Oxford.

SPEck, J. F., Moulder, J. W. \& Evans, E. A. (1946) The biochemistry of the malaria parasite. V. Mechanism of pyruvate oxidation in the malaria parasite. 7. biol. Chem. 164, 119.

Trevelyan, W. E., Proctor, D. P. \& Harrison, J. S. (1950) Detection of sugars on paper chromatograms. Nature, Lond. 166, 444.

Waites, G. M. H. \& Moule, G. R. (1961) Relation of vascular heat exchange to temperature regulation in the testis of the ram. F. Reprod. Fert. 2, 213.

Walton, A. (1956) The initiation of motility in mammalian spermatozoa. Stud. Fert. 8, 53.

WARREN, L. (1959) Sialic acid in the human semen and in the male genital tract. F. clin. Invest. 38, 755. 
Watson, M. (1872) Contributions to the anatomy of the Indian elephant, Part II. Urinary and generative organs. 7. Anat. Physiol., Lond. 6, 60.

Wrber, M. (1898) Siudien über Säugethiere. Fischer, Jena.

Weber, M. (1927) Die Säugetiere, Vol. 1, p. 371. Gustav Fischer, Jena.

Wilson, J. C. C. (1922) The breeding of elephants in captivity. J. Bombay nat. Hist. Soc. 28, 1128.

WisLocki, G. B. (1933) Location of the testes and body temperature in mammals. Q. Rev. Biol. 8, 385.

\section{EXPLANATIONS OF PLATES}

\section{Plate 1}

Fig. 1. Left lateral view of abdominal cavity of bull No. 2, to show the position of the testis and wolffian duct (arrowed).

FIG. 2. Dissected reproductive organs of bull No. 2, showing terminal part of one wolffian duct, seminal vesicles, prostates, and a hemi-section of testis. Matchbox for scale.

Fig. 3. Histological section of testis of bull No. 1, showing large tubules, active spermatogenesis, but relatively little interstitial tissue. $\times 100$.

Frg. 4. Histological section of testis of bull No. 3, showing large tubules, active spermatogenesis, and abundant interstitial tissue. $\times 100$.

\section{Plate 2}

FIg. 1. Dissection of ductuli efferentes and proximal part of wolffian duct of bull No. 7 . Scale in $\mathrm{cm}$.

FIG. 2. Histological appearance of junction of ductuli efferentes (R) with wolffian duct (L) in bull No. $3 . \times 30$.

Frg. 3. Histological appearance of folds in terminal portion of wolffian duct of bull No. 3 . $\times 200$.

Fig. 4. Lining of seminal vesicle of bull No. 3. $\times 1 \cdot 3$.

\section{Plate 3}

Frg. 1. Histological appearance of bulbo-urethral gland of bull No. $3 . \times 160$.

Fig. 2. Bull No. 2 immediately after death, showing discharge of temporal gland secretion down side of face. Position of temporal gland duct is indicated by arrow. White spot on the edge of the secretion is a tick (Amblyomma sp.)

Fig. 3. Section through temporal gland of female elephant showing stick lying in duct. $\times 1 \cdot 3$.

Fig. 4. Spermatozoa from wolffian duct of bull No. 3, stained with eosin and nigrosin. $\times 500$. 
PIATE 1

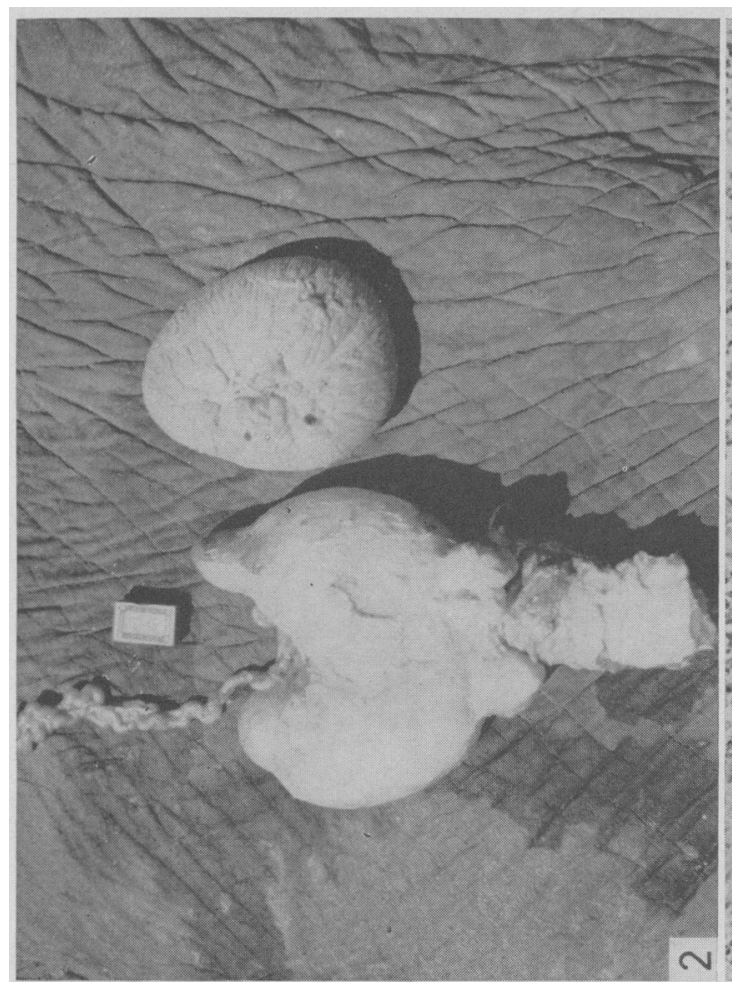
(3)

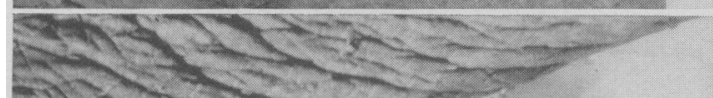

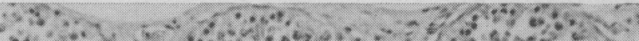

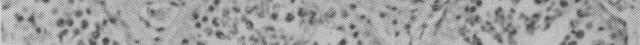

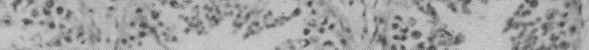
t.

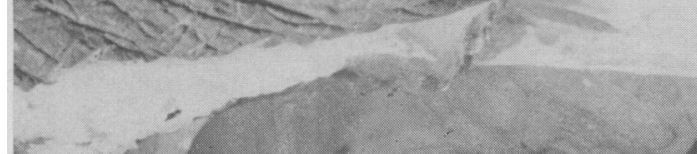

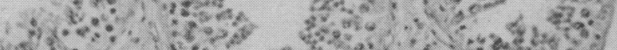

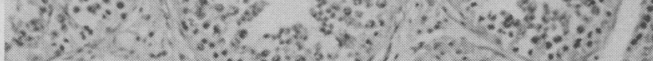
t.

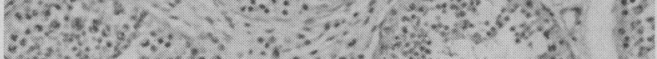
8. (3)

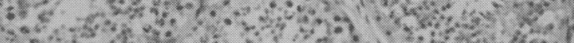

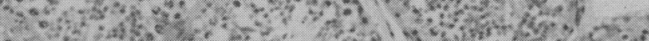

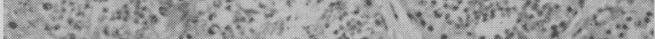

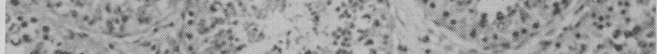

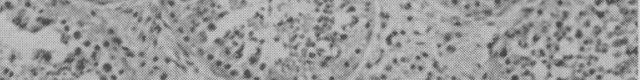

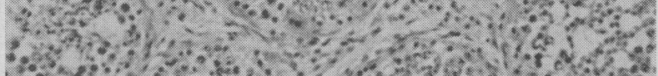
2.

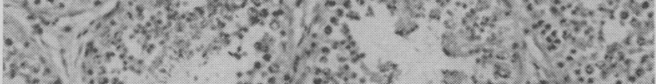
ง

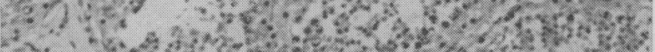
F

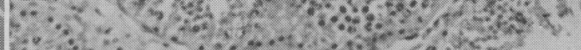

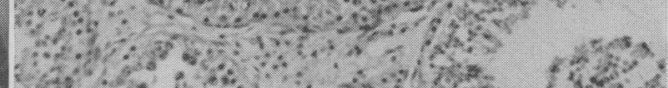

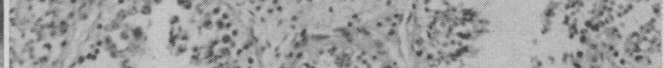

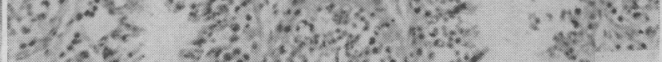
- 
PI.ATE 2

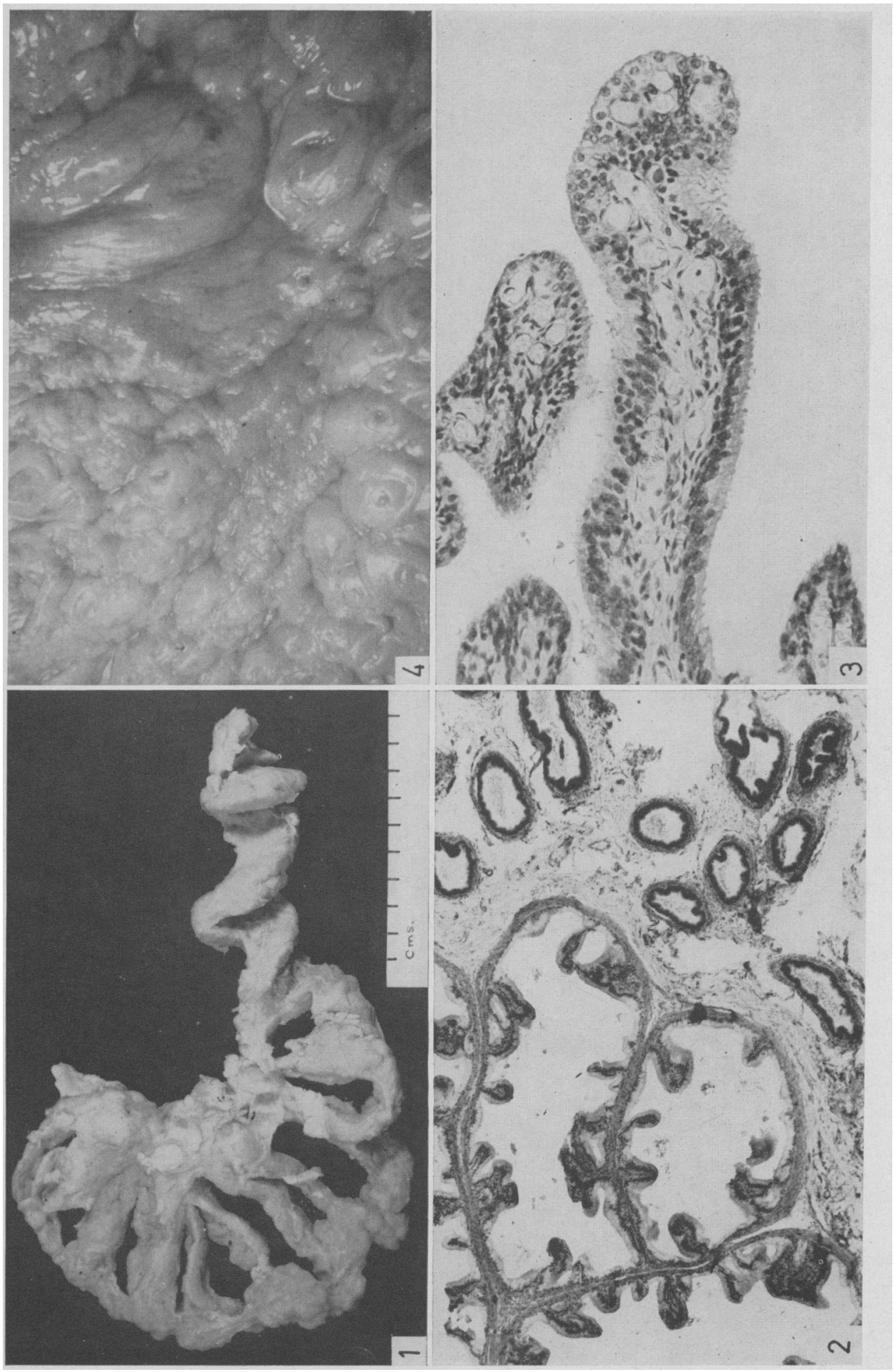


PIAIF:3

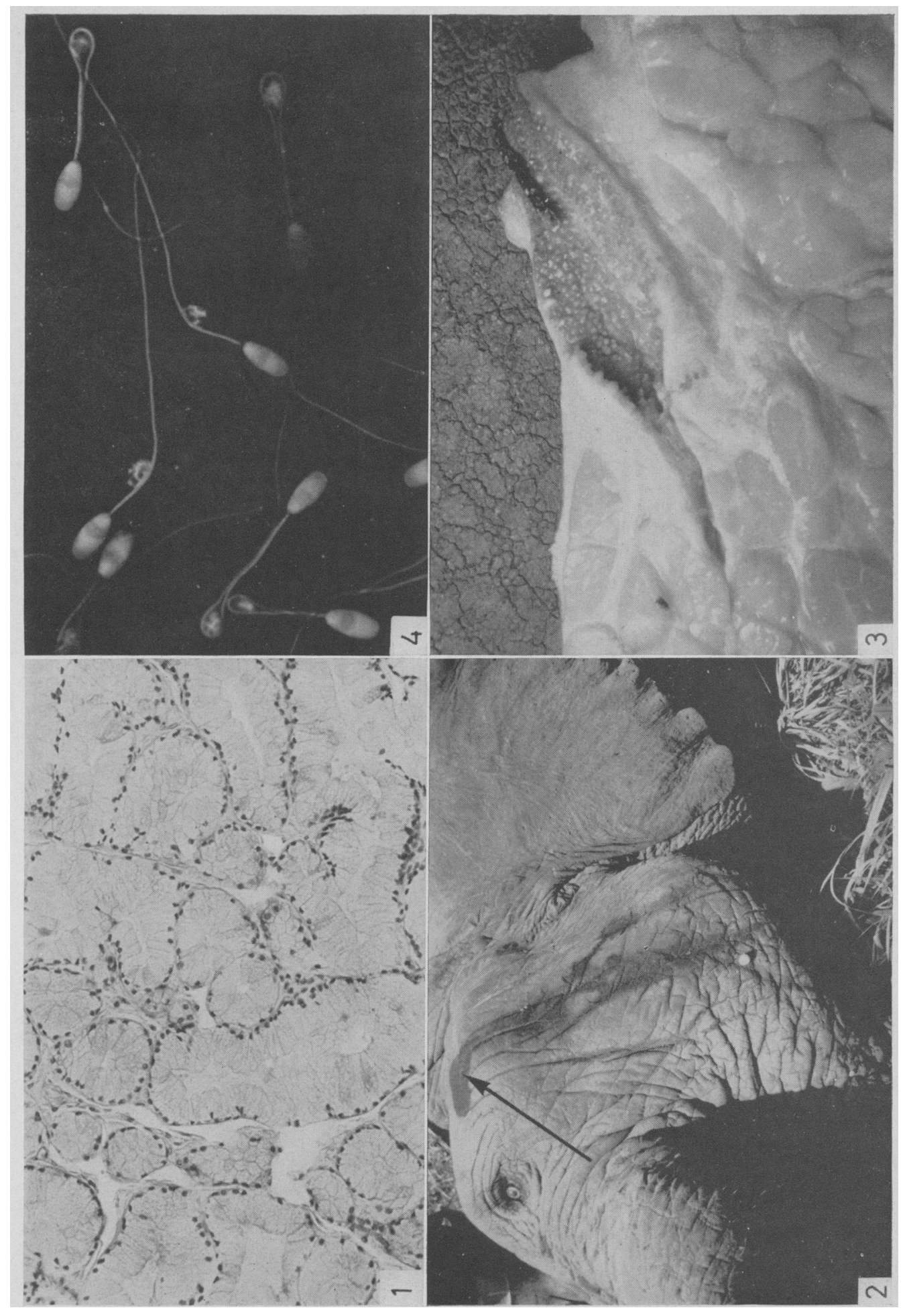

